\title{
ANALISIS STATISTIK DESKRIPTIF SURVEI BAURAN PEMASARAN PADA TOKO BUKU KARISMA BALIKPAPAN
}

\author{
Sasmoyo Dimas Radityo \\ STIE Madani Balikpapan
}

\begin{abstract}
ABSTRAK
Penelitian ini bertujuan untuk menganalisis survei bauran pemasaran pada Toko Buku Karisma di Kota Balikpapan. Bauran pemasaran yang terdiri dari produk, harga, lokasi, dan promosi dapat mempengaruhi berbagai faktor dari seorang konsumen seperti keputusan dalam pembelian dan kepuasan pelanggan. Diharapkan melalui penelitian ini, dapat diketahui indikator-indikator yang dapat ditingkatkan dan diperbaiki oleh perusahaan. Metode analisis yang akan digunakan dalam penelitian ini adalah statistik deskriptif untuk mendapatkan gambaran tentang bauran pemasaran yang lebih mendalam melihat dari hasil survei berupa jawaban kuesioner dari responden.
\end{abstract}

Kata kunci : Analisis Statistik Deskriptif, Bauran Pemasaran

\section{PENDAHULUAN}

Dengan maraknya e-book dan e-shop yang menjual buku secara daring, pada saat ini masih ada perusahaan dan toko yang menjual buku secara konvensional. Perusahaan dan toko tersebut bahkan tidak hanya menawarkan buku, tetapi juga produk-produk lainnya seperti alat tulis dan perlengkapan kantor serta kebutuhan sekolah. Perusahaan toko buku mencoba menarik perhatian konsumen dengan menjual produk lainnya selain buku, karena diketahui bahwa pada saat ini minat baca masyarakat semakin menurun dan juga adanya kemudahan untuk membaca buku secara online. Hal ini dibuktikan dengan adanya pernyataan dari Wakil Ketua Bidang Humas, Riset, dan Informasi Ikatan Penerbit Indonesia (IKAPI) Pusat, Indra Laksana mengatakan bahwa penjualan buku mengalami penurunan, salah satunya disebabkan interaksi masyarakat Indonesia yang kuat dengan internet. IKAPI melihat minat baca meningkat, tetapi interaksinya sudah multimedia bukan hanya buku. Ada peningkatan minat baca, tetapi berbasis daring yaitu materi-materi yang ada pada buku saat ini lebih mudah ditemukan di internet. Dengan kata kunci di mesin pencari, informasi yang diperlukan sudah terpampang di layar komputer atau perangkat genggam tanpa perlu buku dan membolak-balikkan halamannya. Karena itu, bila dilihat dari sisi penerbit konvensional, volume penerbitan dan jumlah toko buku mengalami penurunan (republika.co.id, 2017).

Objek dalam penelitian ini adalah Toko Buku Karisma Balikpapan yang berlokasi di lantai satu Plaza Rapak, Jalan Soekarno Hatta, Kelurahan Muara 
Rapak, Kecamatan Balikpapan Utara, Kalimantan Timur, kode pos 76124. Toko buku ini merupakan salah satu toko buku yang ada di Balikpapan yang berdiri pada tahun 2003. Toko Buku Karisma merupakan sebuah usaha ritel yang menerima buku-buku dari penerbit atau distributor dan produk lainnya untuk dijual kembali. Dalam usahanya Toko Buku Karisma Balikpapan menjual berbagai macam buku dengan klasifikasi dan judul buku yang beragam. Selain itu, Toko Buku Karisma juga menyediakan produk non buku seperti alat tulis dan perlengkapan kantor serta kebutuhan sekolah. Namun, seiring dengan perkembangan zaman dan persaingan yang semakin ketat Toko Buku Karisma Balikpapan harus membuat inovasi baru dan menarik agar dapat bersaing dengan toko buku lainnya. Beberapa pesaing yang sejenis dengan Toko Buku Karisma yang terdapat di kota Balikpapan antara lain Toko Buku Gramedia, Toko Buku Kencana Agung, Books and Beyond serta Pena dan Buku yang akan mendorong persaingan dalam merebut pangsa pasar. Perusahaan-perusahaan tersebut saling berlomba untuk menarik perhatian konsumen sebagai target pasarnya. Merebut dan mempertahankan konsumen agar tetap membeli produk merupakan jalan untuk tetap menjaga kelangsungan hidup perusahaan dan melakukan berbagai pendekatan kepada konsumen untuk mengenal dan memahami berbagai perilaku, kebutuhan, dan keinginan konsumen. Oleh karena itu, perusahaan tidak boleh mengabaikan pendapat atau masukan dari konsumen, karena keberadaan calon konsumen mempunyai pengaruh pada pencapaian tujuan akhir perusahaan yaitu memperoleh laba.

Bauran pemasaran merupakan salah satu strategi pemasaran yang dapat dijalankan oleh suatu perusahaan. Menurut Kotler dalam Sunyoto (2015:202) bauran pemasaran adalah sekelompok kiat pemasaran untuk mencapai sasaran pemasarannya dalam pasar sasaran. Kiat pemasaran tersebut diklasifikasikan ke dalam empat kelompok yaitu produk (product), harga (price), tempat (place), dan promosi (promotion) yang mana ke-empat unsur tersebut pada kenyataannya sangat berpengaruh terhadap capaian volume penjualan, pengambilan keputusan pembelian oleh konsumen, strategi pemasaran, dan target pasar. Strategi bauran pemasaran ini berkaitan dengan penentuan bagaimana perusahaan menyajikan penawaran produk pada segmen pasar tertentu yang merupakan sasaran pasarnya.

Bauran pemasaran yang pertama adalah produk, merupakan salah satu unsur di dalam bauran pemasaran dimana barang atau jasa diperjualbelikan untuk memenuhi kebutuhan dan keinginan bagi seseorang yang mengonsumsinya. Menurut Irawan dalam Sunyoto (2015:69) produk adalah sesuatu yang ditawarkan dan dapat memuaskan keinginan dan kebutuhan konsumen. Produk merupakan salah satu aset perusahaan untuk dapat bertahan dalam dunia bisnis. Kebanyakan konsumen mengharapkan produk yang dibelinya adalah produk yang berkualitas baik. Jika kualitas produk yang diharapkan oleh konsumen tidak terpenuhi dari suatu produk, maka konsumen akan beralih ke produk yang lebih menjanjikan kualitas yang diharapkan. Menurut Kotler (2008:24) selain kualitas produk, atribut produk yang juga diperhatikan oleh konsumen yaitu keberagaman produk, desain dan fitur produk, nama merek, kemasan, layanan, jaminan, dan pengembalian. Atribut-atribut produk tersebut sangat berpengaruh terhadap reaksi konsumen akan suatu produk. Atribut produk merupakan salah satu faktor yang menentukan tinggi rendahnya nilai untuk produk yang ditawarkan oleh 
perusahaan. Jika perusahaan selalu memperhatikan atribut produk tersebut, maka akan meningkatkan volume penjualan dan memberikan keputusan yang baik kepada calon konsumen untuk melakukan pembelian produk. Produk yang tersedia di Toko Buku Karisma Balikpapan bukan hanya buku, tetapi ada produk lain seperti alat tulis dan perlengkapan kantor serta kebutuhan sekolah. Dari hasil observasi di lapangan peneliti melihat koleksi produk pada Toko Buku Karisma Balikpapan mulai dari buku, alat tulis dan perlengkapan kantor serta kebutuhan sekolah beragam, tetapi kurang lengkap dan jarang diperbarui, desain dan fitur dari produk yang tersedia juga standar seperti pada umumnya, sehingga disinyalir hal tersebut yang menyebabkan konsumen beralih ke toko buku lain. Apabila Toko Buku Karisma tidak dapat memperhatikan kualitas dan keberagaman dari produknya, maka Toko Buku Karisma harus menanggung tidak loyalnya konsumen terhadap produk tersebut yang mengakibatkan penjualan dari produk tersebut akan menurun.

Bauran pemasaran yang kedua yaitu harga, adalah sejumlah uang yang dikeluarkan untuk memperoleh suatu barang atau jasa yang diinginkan. Harga merupakan satu-satunya unsur bauran pemasaran yang menghasilkan penerimaan penjualan, sedangkan unsur lainnya hanya unsur biaya saja. Menurut Kotler (2008:24) atribut harga yang selalu diperhatikan oleh konsumen sebelum membeli suatu produk antara lain, harga terdaftar, diskon, potongan harga, periode pembayaran, dan syarat kredit. Walaupun penetapan harga merupakan soal penting, tetapi masih banyak perusahaan yang kurang sempurna dalam menangani permasalahan penetapan harga tersebut (Assauri, 2014:223). Harga produk yang dijual pada Toko Buku Karisma Balikpapan sangat beragam tergantung jenis produk yang ditawarkan. Toko Buku Karisma Balikpapan menawarkan produknya khususnya buku dengan harga yang lebih murah, tetapi kualitas dari buku yang ditawarkan tersebut memang lebih rendah dibandingkan dengan toko buku lainnya.

Lokasi merupakan unsur lainnya dalam bauran pemasaran. Lokasi menjadi faktor penentu banyak tidaknya penjualan, dimana penentuan lokasi yang strategis, banyak dilewati kendaraan, terletak di tengah kota, dan suasana tempat yang ramai, sehingga memudahkan konsumen untuk menjangkau lokasi yang dituju. Menurut Kotler (2008:24) beberapa hal yang diperhatikan oleh konsumen sebelum melakukan pembelian suatu produk yang berkaitan dengan tempat antara lain, saluran, cakupan, pilihan, lokasi, persediaan, dan transportasi. Toko Buku Karisma Balikpapan berada di sebuah pusat perbelanjaan yang mana mudah diakses oleh transportasi umum dan dekat dengan pintu masuk utama lantai satu Plaza Rapak. Awalnya, Toko Buku Karisma Balikpapan mendapatkan 3 spaces, tetapi saat pendapatan mulai menurun Toko Buku Karisma hanya menempati satu space saja dan hal ini tentu akan berpengaruh pada kenyamanan konsumen saat melakukan kunjungan ke Toko Buku Karisma Balikpapan.

Bauran pemasaran yang terakhir adalah promosi. Menurut Gitosudarmo dalam Sunyoto (2014:155) promosi merupakan kegiatan yang ditujukan untuk memengaruhi konsumen agar mereka dapat menjadi kenal akan produk yang ditawarkan oleh perusahaan kepada mereka dan kemudian mereka menjadi senang lalu membeli produk tersebut. Promosi berfungsi untuk mempengaruhi sikap dan 
kesukaan konsumen dalam memilih produk serta untuk memotivasi konsumen mengambil tindakan positif yaitu melakukan keputusan pembelian terhadap produk yang ditawarkan. Menurut Kotler (2008:24) beberapa hal yang diperhatikan oleh konsumen sebelum melakukan pembelian suatu produk berkaitan dengan promosi antara lain, promosi penjualan, periklanan, tenaga penjualan, hubungan masyarakat, dan pemasaran langsung. Promosi yang dapat dilakukan oleh suatu perusahaan toko buku misalnya melalui iklan di media cetak atau elektronik dan menjadi sponsor di event-event tertentu. Kondisi yang terjadi di Toko Buku Karisma Balikpapan pada awalnya terdapat promosi berupa discount sebesar $10 \%$ sampai dengan $15 \%$ bagi konsumen yang memiliki kartu member dan dengan pembelian $>50$ produk, selain itu Toko Buku Karisma Balikpapan juga sering mengadakan atau menjadi salah satu sponsor event sekaligus melakukan pengenalan produk-produk baru mereka, tetapi sejak mengalami penurunan pendapatan, promosi tersebut sudah tidak dilakukan lagi.

Berdasarkan penjelasan bauran pemasaran Toko Buku Karisma di atas, peneliti mengambil beberapa kesimpulan diantaranya, karena produk di toko buku lain lebih berkualitas, beragam, dan up to date, harga di toko buku lain sesuai dengan produk yang ditawarkan, sedangkan di Toko Buku Karisma Balikpapan harga produk khususnya buku lebih murah dan kualitas buku yang ditawarkan memang lebih rendah dibandingkan dengan toko buku lainnya, tempat/lokasi yang termasuk di dalamnya suasana di ruangan toko yang lebih nyaman dibandingkan dengan Toko Buku Karisma Balikpapan, dan promosi di toko buku lain lebih menarik, sedangkan di Toko Buku Karisma Balikpapan tidak lagi melakukan pengenalan produknya lewat event-event ataupun memberikan diskon.

Berdasarkan uraian di atas, penulis tertarik untuk menganalisis bauran pemasaran pada Toko Buku Karisma di Balikpapan. Penelitian ini akan mengolah dan menganalisis data survei hasil penyebaran kuesioner kepada pelanggan Toko Buku Karisma mengenai bauran pemasaran, maka penulis melakukan penelitian yang berjudul "Analisis Statistik Deskriptif Survei Bauran Pemasaran Pada Toko Buku Karisma Balikpapan”.

\section{KERANGKA TEORI}

Menurut Suharno dan Sutarso (2010:27-28) bauran pemasaran adalah kumpulan aktivitas pemasaran yang digunakan untuk melayani pasar sasaran. Bauran pemasaran dibuat dalam satuan unit segmen pasar, sehingga masingmasing segmen memerlukan bauran pemasaran yang berbeda. Bauran pemasaran terdiri dari empat aktivitas utama, yaitu produk, harga, distribusi, dan promosi. Keempat aktivitas tersebut harus terintegrasi, dalam arti masing-masing saling berhubungan dan saling mendukung. Integrasi ini perlu dicapai agar dampak dari bauran pemasaran dapat lebih besar. Adapun empat aktivitas utama dalam bauran pemasaran antara lain:

1. Produk, berarti kombinasi barang atau jasa yang ditawarkan oleh perusahaan kepada pasar sasaran. Produk tidak saja barang atau jasa, namun entitas lain seperti ide, organisasi, orang, tempat juga merupakan produk. Masing-masing 
jenis produk memiliki cara yang berbeda dalam pemasarannya. Pasar sasaran memandang produk baik adalah dari bagaimana produk memberikan solusi bagi kebutuhan dan keinginan konsumen.

2. Harga, adalah sejumlah uang yang digunakan untuk mendapatkan barang atau jasa. Harga memiliki berbagai ragam istilah, tergantung pada jenis produknya apa. Yang terpenting bagi pelanggan dalam kaitan dengan harga adalah bagaimana harga mencerminkan biaya pelanggan.

3. Distribusi, adalah usaha-usaha pemasar untuk menjamin ketersediaan produk bagi pasar sasaran pada saat dibutuhkan. Pemasar perlu menjamin bahwa produk yang ditawarkan akan tersedia pada saat konsumen membutuhkan dimanapun, kapanpun, dan berapapun. Aktivitas terpenting dari distribusi dalam menjaga kemudahan dan kenyamanan dalam memperoleh produk yang diinginkan pasar sasaran.

4. Promosi, adalah aktivitas komunikasi pemasaran mengenai produk dan mempersuasi pasar sasaran untuk membelinya. Aktivitas promosi banyak menyangkut bagaimana mengkomunikasikan dan mempersuasi pelanggan. Upaya ini dapat dijalankan dengan berbagai bentuk baik periklanan, promosi penjualan, penjualan pribadi maupun kehumasan. Yang terpenting dari kegiatan ini adalah bagaimana bisa berkomunikasi dengan pasar sasaran.

\section{METODE PENELITIAN}

Dalam penelitian ini, metode pengumpulan data yang digunakan yaitu kuesioner tertutup dengan pengukuran skala likert. Menurut Sugiyono (2014:132133) skala likert digunakan untuk mengukur sikap, pendapat, dan persepsi seseorang atau sekelompok orang tentang fenomena sosial. Dalam penelitian, fenomena sosial ini telah ditetapkan secara spesifik oleh peneliti yang selanjutnya disebut dengan variabel penelitian. Dengan skala likert, maka variabel yang akan diukur dijabarkan menjadi indikator variabel. Kemudian indikator tersebut dijadikan sebagai titik tolak untuk menyusun item-item instrumen yang dapat berupa pernyataan atau pertanyaan. Berdasarkan penelitian yang dilakukan oleh Mawahib (2015) jawaban setiap instrumen yang menggunakan skala likert mempunyai gradasi dari sangat positif sampai dengan sangat negatif yang dapat berupa kata-kata antara lain:

1. Sangat Tidak Setuju (STS) diberi skor $\quad: 1$

2. Tidak Setuju (TS) diberi skor $\quad: 2$

3. Netral $(\mathrm{N})$ diberi skor $: 3$

4. Setuju (S) diberi skor $\quad: 4$

5. Sangat Setuju (SS) diberi skor $\quad: 5$ 
Untuk mendapatkan penggambaran data tentang statistik data yang lebih mendalam dari survei bauran pemasaran pada Toko Buku Karisma Balikpapan maka digunakan statistik deskriptif melalui bantuan program Excel dengan cara mencari dan membandingkan nilai mean dari masing-masing atribut yang diukur.

\section{HASIL DAN PEMBAHASAN}

\section{Tabel 1}

\section{Statistik Deskriptif Survei Bauran Pemasaran Pada Toko Buku Karisma Balikpapan}

\begin{tabular}{|c|c|}
\hline Bauran Pemasaran & Rata-rata Jawaban Kuesioner Responden \\
\hline Produk & 3,1 \\
\hline Harga & 3,5 \\
\hline Lokasi & 3,8 \\
\hline Promosi & 3,17 \\
\hline
\end{tabular}

Tabel 1 adalah hasil pengolahan dari jawaban survei bauran pemasaran pada Toko Buku Karisma Balikpapan dengan jumlah 115 responden dengan interval jawaban $1-5$, yang artinya semakin kecil angkanya menandakan semakin tidak setuju dengan pernyataan dan semakin besar angkanya menandakan semakin setuju dengan pernyataan. Variabel produk dengan 4 atribut yang diukur menghasilkan rata-rata jawaban dari responden sebesar 3,1. Berikutnya variabel harga dengan 4 atribut yang diukur menghasilkan rata-rata jawaban dari responden sebesar 3,5. Sedangkan variabel lokasi dengan 5 atribut yang diukur menghasilkan rata-rata jawaban dari responden sebesar 3,8. Terakhir variabel promosi dengan 4 atribut yang diukur menghasilkan rata-rata jawaban dari responden sebesar 3,17.

Tabel 2

\section{Statistik Deskriptif Survei Bauran Pemasaran per Atribut Pada Toko Buku Karisma Balikpapan}

\begin{tabular}{|c|l|c|}
\hline No. & \multicolumn{1}{|c|}{ Atribut yang diukur } & \multicolumn{1}{|c|}{$\begin{array}{c}\text { Rata-rata Jawaban } \\
\text { Kuesioner Responden }\end{array}$} \\
\hline & Produk & 3,1 \\
\hline 1 & $\begin{array}{l}\text { Toko Buku Karisma Balikpapan menawarkan jenis-jenis } \\
\text { produk yang lengkap. }\end{array}$ & 2,8 \\
\hline 2 & $\begin{array}{l}\text { Toko Buku Karisma Balikpapan menawarkan jenis-jenis } \\
\text { produk yang berkualitas baik. }\end{array}$ & 3,4 \\
\hline 3 & $\begin{array}{l}\text { Toko Buku Karisma Balikpapan selalu memberikan } \\
\text { informasi tentang produk baru. }\end{array}$ & 2,9 \\
\hline 4 & $\begin{array}{l}\text { Toko Buku Karisma Balikpapan akan menjamin apabila } \\
\text { produk tidak berfungsi sebagaimana diharapkan. }\end{array}$ & 3,2 \\
\hline
\end{tabular}




\begin{tabular}{|c|l|c|}
\hline & Harga & 3,5 \\
\hline 1 & Harga barang-barang yang ditawarkan relatif terjangkau. & 3,6 \\
\hline 2 & $\begin{array}{l}\text { Harga barang-barang yang ditawarkan sesuai dengan } \\
\text { kualitas barang. }\end{array}$ & 3,8 \\
\hline 3 & $\begin{array}{l}\text { Harga barang-barang yang ditawarkan cukup bersaing } \\
\text { dengan pesaing lain. }\end{array}$ & 3,6 \\
\hline 4 & Potongan harga / diskon yang diberikan cukup besar. & 3 \\
\hline & Lokasi & 3,8 \\
\hline 1 & $\begin{array}{l}\text { Letak Toko Buku Karisma Balikpapan sangat strategis } \\
\text { sehingga bisa diakses oleh berbagai alat transportasi. }\end{array}$ & 3,9 \\
\hline 2 & Tersedia lahan parkir yang luas. & 4 \\
\hline 3 & Lokasi dilalui transportasi umum. & 3,4 \\
\hline 4 & $\begin{array}{l}\text { Di daerah Toko Buku Karisma Balikpapan mempunyai } \\
\text { pesaing yang menjual kebutuhan yang sama seperti Toko } \\
\text { Buku Karisma Balikpapan. }\end{array}$ & 3,3 \\
\hline 5 & $\begin{array}{l}\text { Papan nama Toko Buku Karisma Balikpapan terlihat jelas } \\
\text { dan menarik. }\end{array}$ & 3,17 \\
\hline & Promosi & $\begin{array}{l}\text { Toko Buku Karisma Balikpapan melakukan promosi } \\
\text { melalui media sosial. }\end{array}$ \\
\hline 2 & $\begin{array}{l}\text { Toko Buku Karisma Balikpapan menyediakan sampel } \\
\text { untuk setiap produk. }\end{array}$ & 3,4 \\
\hline 3 & $\begin{array}{l}\text { Toko Buku Karisma Balikpapan menyediakan layanan } \\
\text { pusat informasi yang siap membantu konsumen. }\end{array}$ & 3,2 \\
\hline \multirow{2}{*}{4} & $\begin{array}{l}\text { Program promosi yang dilakukan oleh Toko Buku } \\
\text { Karisma Balikpapan adalah dengan mengadakan pameran } \\
\text { di depan Toko Buku Karisma tersebut dan pemberian } \\
\text { potongan harga (discount). }\end{array}$ & \\
\hline
\end{tabular}

Tabel 2 adalah hasil pengolahan dari jawaban survei bauran pemasaran per atribut pada Toko Buku Karisma Balikpapan dengan jumlah 115 responden dengan interval jawaban $1-5$, yang artinya semakin kecil angkanya menandakan semakin tidak setuju dengan pernyataan dan semakin besar angkanya menandakan semakin setuju dengan pernyataan. Untuk variabel produk, atribut Toko Buku Karisma Balikpapan menawarkan jenis-jenis produk yang lengkap memiliki nilai rata-rata jawaban terkecil sebesar 2,8 sedangkan atribut Toko Buku Karisma Balikpapan menawarkan jenis-jenis produk yang berkualitas baik memiliki nilai rata-rata jawaban terbesar dengan angka 3,4.

Pada variabel harga, atribut potongan harga / diskon yang diberikan cukup besar memiliki nilai rata-rata jawaban terkecil dengan angka 3, sedangkan atribut harga barang-barang yang ditawarkan sesuai dengan kualitas barang memiliki nilai rata-rata jawaban terbesar dengan angka 3,8. Untuk variabel lokasi yang memiliki 5 atribut, atribut papan nama Toko Buku Karisma Balikpapan terlihat jelas dan menarik memiliki nilai rata-rata jawaban terkecil dengan angka 3,3 sedangkan atribut lokasi dilalui transportasi umum memiliki nilai rata-rata jawaban terbesar dengan angka 4. Kemudian variabel promosi dengan 4 atribut, atribut Toko Buku Karisma Balikpapan melakukan promosi melalui media sosial memiliki nilai rata-rata jawaban terkecil dengan angka 3, sedangkan atribut Toko Buku Karisma Balikpapan menyediakan layanan pusat informasi yang siap membantu konsumen memiliki nilai rata-rata jawaban terbesar dengan angka 3,4. 
Berdasarkan tabel 1, menurut 115 responden yang disurvei dihasilkan bahwa variabel lokasi memiliki nilai rata-rata jawaban terbesar dibandingkan bauran pemasaran lainnya pada Toko Buku Karisma Balikpapan. Toko Buku Karisma Balikpapan berada di sebuah pusat perbelanjaan yang mana mudah diakses oleh transportasi umum dan dekat dengan pintu masuk utama lantai satu Plaza Rapak. Awalnya, Toko Buku Karisma Balikpapan mendapatkan 3 spaces, tetapi saat pendapatan mulai menurun Toko Buku Karisma hanya menempati satu space saja. Walaupun mengalami perubahan tempat yang lebih kecil, responden menilai variabel lokasi merupakan bauran pemasaran yang paling dirasakan baik pada Toko Buku Karisma Balikpapan. Dimana atribut yang dinilai seperti letak yang strategis sehingga bisa diakses oleh berbagai alat transportasi, lahan parkir yang luas, lokasi yang dilalui transportasi umum, dan papan nama yang terlihat jelas dan menarik mendapatkan respon yang baik dari responden. Toko Buku Karisma Balikpapan sebaiknya memanfaatkan variabel lokasi ini sebagai kekuatan di dalam mencapai tujuannya seperti mendatangkan pelanggan dan bersaing dengan toko sejenis lainnya di kota Balikpapan.

Kemudian menurut 115 responden yang disurvei dihasilkan bahwa variabel produk memiliki nilai rata-rata jawaban terkecil dibandingkan bauran pemasaran lainnya pada Toko Buku Karisma Balikpapan. Produk yang tersedia di Toko Buku Karisma Balikpapan bukan hanya buku, tetapi ada produk lain seperti alat tulis dan perlengkapan kantor serta kebutuhan sekolah. Dari hasil observasi di lapangan peneliti melihat koleksi produk pada Toko Buku Karisma Balikpapan mulai dari buku, alat tulis dan perlengkapan kantor serta kebutuhan sekolah beragam, tetapi kurang lengkap dan jarang diperbarui, desain dan fitur dari produk yang tersedia juga standar seperti pada umumnya. Dimana atribut yang dinilai seperti kelengkapan jenis-jenis produk, kualitas produk, informasi tentang produk baru, dan jaminan apabila produk tidak berfungsi sebagaimana diharapkan dianggap masih kurang cukup bagi responden. Maka berdasarkan uraian ini sebaiknya Toko Buku Karisma Balikpapan mulai memperhatikan dan meningkatkan penerapan strategi produknya, karena variabel produk merupakan salah satu faktor utama sebuah toko/perusahaan untuk menarik pelanggan dan mempertahankan posisinya di pasar dalam persaingan dengan toko/perusahaan lainnya. Sedangkan berdasarkan tabel 2 dari 115 responden yang disurvei dari 19 atribut yang diukur dihasilkan bahwa atribut lokasi yang dilalui transportasi umum mendapatkan nilai rata-rata jawaban terbesar. Lokasi yang mudah diakses dan dilalui transportasi umum menjadi poin positif bagi konsumen Toko Buku Karisma Balikpapan dalam mencari kebutuhannya di toko tersebut. Sedangkan atribut kelengkapan jenis-jenis produk mendapatkan nilai rata-rata jawaban terkecil. Konsumen Toko Buku Karisma Balikpapan menilai bahwa atribut tersebut adalah penting namun belum cukup dipenuhi oleh pihak toko/perusahaan.

\section{PENUTUP}

Berdasarkan hasil pengolahan data dan pembahasan di bab 4, dapat disimpulkan bahwa variabel lokasi dan atribut lokasi yang mudah dilalui transportasi umum mendapatkan respon yang paling baik dari bauran pemasaran pada Toko Buku Karisma Balikpapan. Sedangkan variabel produk dan atribut 
kelengkapan jenis-jenis produk mendapatkan respon yang paling kurang baik. Dalam penelitian ini peneliti dapat memberikan saran dalam strategi bauran pemasaran bahwa sebaiknya Toko Buku Karisma Balikpapan memanfaatkan kekuatannya dalam hal lokasi dan kemudahannya untuk dilalui transportasi umum. Kemudian Toko Buku Karisma Balikpapan juga sebaiknya memperhatikan dan meningkatkan strateginya dalam pengadaan produk khususnya kelengkapan jenis-jenis produk yang ditawarkan kepada konsumennya.

\section{DAFTAR PUSTAKA}

Assauri, Sofjan. 2014. Manajemen Pemasaran. Cetakan ke-13. PT Raja Grafindo Persada. Jakarta.

Kotler, Philip dan Kevin L. Keller. 2008. Manajemen Pemasaran. Edisi 12. Jilid 1. Erlangga. Jakarta.

Maharani, Esthi. 2017. IKAPI: Penjualan Buku Menurun. https://www.republika.co.id/berita/pendidikan/eduaction/17/04/25/ooy9ig3 35-ikapi-penjualan-buku-menurun. 18 November 2019. ( 13.23 ).

Malasari, Dewi. 2017. Pengaruh Harga, Produk, Promosi, dan Lokasi terhadap Keputusan Pembelian Konsumen pada Toko Alimudin. Skripsi. Sekolah Tinggi Ilmu Ekonomi Madani (STIE Madani). Balikpapan.

Mawahib, M Jauharul. 2015. Pengaruh Bauran Pemasaran terhadap Keputusan Pembelian Smartphone Samsung (Studi Kasus pada Mahasiswa Adminitrasi Bisnis Universitas Mulawarman). eJournal Administrasi Bisnis 3 (4): 858-872.

Prasetya, Tjoa, Billy Jana. 2015. Pengaruh Bauran Pemasaran (Retailing Mix) terhadap Keputusan Pembelian Konsumen pada Toko Jana Abadi. Skripsi. Sekolah Tinggi Ilmu Ekonomi Madani (STIE Madani). Balikpapan.

Qerja.com. 2019. Profil Karisma Aksara Mediatama PT. https://www.qerja.com/company/view/karisma-aksara-mediatama-pt. 29 November 2019. (20.13).

Sangadji, Etta Mamang dan Sopiah. 2013. Perilaku Konsumen. CV Andi. Yogyakarta.

Suharno dan Yudi Sutarso. 2010. Marketing in Practice. Cetakan ke-1. Graha Ilmu. Yogyakarta.

Sugiyono. 2014. Metode Penelitian Bisnis. Cetakan ke-18. Alfabeta. Bandung. 
Suyonto, Danang. 2014. Dasar-dasar Manajemen Pemasaran (Konsep, Strategi, dan Kasus). Cetakan Ketiga. CAPS. Yogyakarta.

Sunyoto, Danang. 2014. Konsep Dasar Riset Pemasaran dan Perilaku Konsumen. Cetakan Kedua. CAPS. Yogyakarta.

Sunyoto, Danang. 2015. Perilaku Konsumen dan Pemasaran. Cetakan Pertama. CAPS. Yogyakarta. 